\title{
ESTIMATION OF BVOC EMISSIONS IN GUANGZHOU AND ITS SPATIAL- TEMPORAL VARIATIONS: PRELIMINARY RESULTS FROM GLOBEIS
}

\author{
Lili Li ${ }^{1}$, Yunpeng Wang ${ }^{1}$, Yangcheng Zheng ${ }^{1,2}$, Tao Chen ${ }^{3, *}$ \\ ${ }^{1}$ Guangzhou Institute of Geochemistry, Chinese Academy of Sciences, Guangzhou \\ 510640, China \\ ${ }^{2}$ University of Chinese Academy of Sciences, Beijing 100082, P R China \\ 3. The Environmental Research Institute; MOE Key Laboratory of Theoretical Chemistry of Environment, South China Normal \\ University, Guangzhou 510006, P R China \\ tao.chen@m.scnu.edu.cn
}

Commission III, WG III/8

KEY WORDS: Biogenic volatile organic compounds (BVOC), Spatial-temporal variations, Global Biosphere Emission and Interactions System (GloBEIS) model, Emission factors

\begin{abstract}
:
Biogenic VOC emissions greatly exceed anthropogenic emissions and are regarded as significant precursors to secondary organic aerosol (SOA) and ozone. Using the Global Biosphere Emission and Interactions System (GloBEIS) model, $1 \times 1 \mathrm{~km}$ gridded and hourly BVOC emissions in Guangzhou were estimated for the year of 2012. This study used satellite-retrieved land cover data, cloud product and leaf area index (LAI), observed meteorological data and local emission rates for land cover types in South China. The result show that the total BVOC emission in Guangzhou, 2012 was $4.39 \mathrm{kt}$ and the average area emission was $5.93 \mathrm{t} /\left(\mathrm{km}^{2} \bullet \mathrm{a}\right)$, of which isoprene contributed about $55.7 \%(2.44 \mathrm{kt})$ ), monoterpenes about $11.9 \%(0.52 \mathrm{kt})$ and OVOC about $32.4 \%$ (1.42 kt). Emission factors of land cover types and correction parameters including LAI, wind speed and relative humidity have great effects on the estimation results of the model. BVOC emissions in Guangzhou exhibit a marked monthly and seasonal pattern with the peak emission in July to August and the lowest emission in January and are mainly distributed in the east-western of Conghua, the north of Zengcheng and the border of Huadu and Conghua, mostly covered by evergreen broadleaf forest with high emission factor, while areas of BVOC emission below $50 \mathrm{~kg} /\left(\mathrm{km}^{2} \bullet\right.$ a) are distributed in highly urbanized areas like Tianhe, Yuexiu, Liwan and Haizhu district.
\end{abstract}

\section{INTRODUCTION}

Volatile organic compounds (VOCs) have great impacts on the atmospheric environment and climate, due to their high activity in photochemical reaction with nitrogen oxides and hydroxyl radical $(\mathrm{OH})$ in the tropospheric air. Biogenic VOCs, mainly originating from vegetation, have been regarded as key precursors to secondary organic aerosol (SOA) and important sources of carbon budget, thus playing an important role in atmospheric aerosol burden and carbon cycle processes (Arneth et al., 2008; Goldstein and Galbally, 2007; Karl et al., 2009; Li et al., 2012).

Emissions of biogenic VOCs have been estimated to greatly exceed anthropogenic emissions on the global scale, among which isoprene and monoterpene are key sources of secondary aerosol particles and ozone (Carslaw et al., 2010; Nozière et al., 2011). The global annual emissions of BVOCs, isoprene and monoterpenes were estimated to be in the range of $500-1150 \mathrm{Tg}$ C yr-1, 220-601 Tg C yr-1and 32-157 Tg C yr-1, respectively (Guerther et al., 1995, 2006, 2012; Tao et al., 2005; Arneth et al., 2008; Schurgers et al., 2009). In China, the annual BVOCs, isoprene and monoterpene emissions were estimated to be 12.83-42.5 Tg C yr-1, 4.1-20.7 Tg C yr-1 and 2.23-6.2 Tg C yr1, respectively (Guenther et al., 1995; Klinger et al., 2002; Tie et al., 2006; Chi and Xie, 2011; Fu and Liao, 2012; Li et al., 2012; Li et al., 2013).

In recent decades, studies on BVOC emissions have been conducted in China, focusing on the spatial and temporal variations of BVOCs, as well as their effects on SOA and ozone. The highest biogenic emissions occurred over south-eastern and south-western China in June-July-August, and the lowest in western China in January-December ( $\mathrm{Li}$ et al., 2012; Fu and Liao, 2012; Li et al., 2013). In the Pearl River Delta (PRD), BVOC emissions in 2006 were estimated to be $0.22 \mathrm{Tg} \mathrm{C}$ and exhibited a seasonal pattern with the peak emission in July and the lowest in January, mainly distributed over the outlying areas of PRD (Zheng et al., 2010; Wang et al., 2011).

Guangzhou, as the provincial capital of Guangdong, is located in the middle-south of Guangdong and north of Pearl River Delta (PRD), with the terrain decreasing from north to south, middle and low mountains in the northeast, hilly basin in the middle, and alluvial plain in the south. The average annual temperature ranges from 21.5 to $22.2{ }^{\circ} \mathrm{C}$, and the annual average rainfall is about $1800 \mathrm{~mm}$. The topography and climate in Guangzhou provide a good ecological environment for the growth of various plants, with a wide range of vegetation types. Therefore, the study of VOCs emission from natural sources in Guangzhou can provide a scientific basis for impacts of vegetation on atmospheric quality, and facilitate the formulation of optimized reduction schemes in line with local pollution characteristics when adopting pollution control countermeasures. Taking Guangzhou as the study area, this paper estimated BVOC emissions in 2012 through GloBEIS model, and explored the impacts of emission rates and correction factors on the estimation results. Finally, spatial and temporal characteristics of BVOC (including isoprene, monoterpenes and other VOCs) are analysed. 


\section{METHODOLOGY AND DATA}

\subsection{GLoBEIS model}

GloBEIS, short for Global Biosphere Emission and Interactions System, is one of the primary biogenic emissions modeling system developed by NCAR (National Center for Atmospheric Research) and Environmental International Corporation. Based on the BEIS emission factors, GloBEIS has an easy-to-use interface compatibility with a wider range of input data sources and enhanced algorithms including canopy environment, leaf age, variable LAI, and the influence of antecedent temperature conditions, as is shown in Figure 1, and is used to estimate biogenic emissions of volatile organic compounds, carbon monoxide and soil NOx emissions for any time scale and domain (Yarwood et al., 2007).

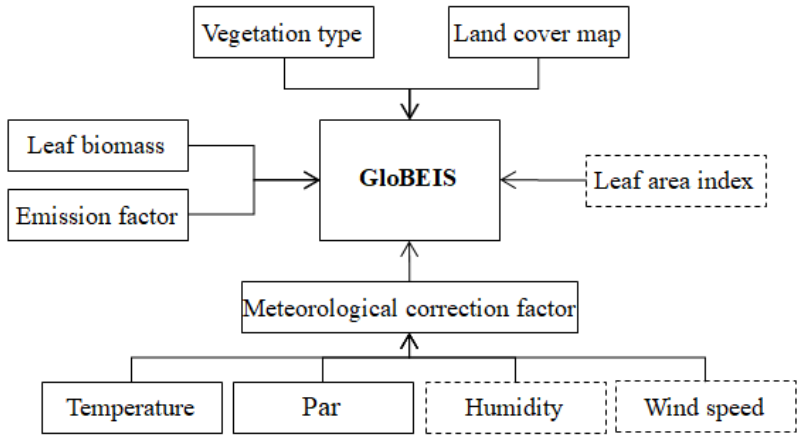

Figure 1. Input parameters for estimation of BVOCs in GloBEIS

In the GloBEIS model. Biogenic VOC emissions are estimated using Eq. (1) (Guenther et al., 2006):

$$
\text { Emission }=\mathrm{D} \varepsilon \gamma
$$

Where $\mathrm{D}\left(\mathrm{gm}^{-2}\right)$ is the foliar density for the vegetation type; $\varepsilon$ $\left.\left(\mu \mathrm{gCg}^{-1} \mathrm{~h}^{-1}\right)\right)$ is the average emission rate of a compound for a certain vegetation type at the temperature of $303.15 \mathrm{~K}$ and photosynthetically active radiation (PAR) of $1000 \mu \mathrm{molm}^{-2} \mathrm{~s}^{-1} ; \gamma$ (a normalized ratio) is an emission activity factor accounting for emission changes due to deviations of temperature and PAR from standard conditions. Because of different dependencies on light and temperature, calculation of $\gamma$ for isoprene is different from that for other two VOC species. The response to changes in light, temperature and leaf age are accounted for in the activity factors for isoprene as follows:

$$
\gamma=\gamma_{P} \cdot \gamma_{T} \cdot \gamma_{L}
$$

As monoterpenes and OVOC emissions depend strongly on temperature, only the influence of temperature is considered as follows:

\subsection{Data}

$$
\gamma=\exp \left[\beta \times\left(T-T_{S}\right)\right]
$$

According to Figure 1, inputs for BVOCs estimation include land cover map, meteorological data, leaf area index and emission index. Land cover data in our study was $500 \mathrm{~m}$ resolution MODIS LUCC product (MCD12Q1) in 2012, with IGBP classification identifying 17 land cover classes. 11 land cover types in Guangzhou were finally extracted through reclassification according to the vegetation distribution map. As for meteorological parameters, $1 \mathrm{~km}$ gridded data of temperature, relative humidity and wind speed were interpolated from measurements of 12 weather stations in Guangzhou. Photosynthetically active radiation (PAR) were retrieved from $1 \mathrm{~km}$ MODIS cloud fraction products (MOD06_L2).

Vegetation types and their emission factors play significant roles in the estimation of BVOC emissions. Lack of detailed spatial distribution of tree species and their measured emission rates in the study area, local emission rate of each land cover type were determined (Table 1), based on relevant studies from other researchers and GloBEIS model.

\begin{tabular}{|l|l|l|l|}
\hline \multirow{2}{*}{ Land cover type } & \multicolumn{3}{|c|}{ Emission factor $\left[\mu \mathrm{gC} /\left(\mathrm{m}^{2} \cdot \mathrm{h}\right)\right]$} \\
\cline { 2 - 4 } & ISOP & TMT & OVOCs \\
\hline Coniferous forest & 890 & 2670 & 1335 \\
\hline Broadleaf forest & 4710 & 510.25 & 1177.5 \\
\hline $\begin{array}{l}\text { Coniferous and broadleaved } \\
\text { mixed forest }\end{array}$ & 840 & 1135 & 1250 \\
\hline Shrub land & 37.8 & 94.5 & 56.7 \\
\hline Grassland & 56.2 & 140.5 & 84.3 \\
\hline Wetland & 1050 & 660 & 770 \\
\hline Dry cropland & 102 & 255 & 153 \\
\hline Irrigated cropland & 7.6 & 19 & 11.4 \\
\hline Water & 0 & 0 & 0 \\
\hline Urban land & 11.2 & 28.1 & 16.9 \\
\hline Barren land & 0 & 0 & 0 \\
\hline
\end{tabular}

Table 1. Emission factors of each land cover type in this study

\section{RESULTS AND DISCUSSION}

\subsection{Estimation of BVOC emissions in Guangzhou}

With the aid of GloBEIS, the hourly and $1 \times 1 \mathrm{~km}$ gridded BVOC emissions in Guangzhou, 2012 were estimated by inputting study domain, vegetation type, temperature and PAR, as well as setting up the local emission rates. The total BVOC emission in Guangzhou was $6.17 \mathrm{kt}$ in 2012, and the area-averaged emission was $8.34 \mathrm{t} /\left(\mathrm{km}^{2} \cdot \mathrm{a}\right)$, of which isoprene contributed about $45.7 \%$ $\left(2.82 \mathrm{kt}, 3.81 \mathrm{t} /\left(\mathrm{km}^{2} \cdot \mathrm{a}\right)\right)$, monoterpenes about $15.8 \%(0.98 \mathrm{kt}$, $\left.1.32 \mathrm{t} /\left(\mathrm{km}^{2} \cdot \mathrm{a}\right)\right)$ and OVOC about $38.4 \%\left(2.37 \mathrm{kt}, 3.21 \mathrm{t} /\left(\mathrm{km}^{2} \cdot \mathrm{a}\right)\right)$. Figure 2 shows the monthly emission variations for the total BVOC, isoprene, monoterpenes and OVOC emission. BVOC emissions exhibit obvious peak to valley characteristics with maximum $(1.02 \mathrm{kt})$ in July and minimum $(0.2 \mathrm{kt})$ in December, because in July high temperature and strong sunlight favoured the VOCs emitted from vegetation, while in December low temperature and weak sunshine prohibited BVOC emissions. Monthly variation for isoprene is more significant than those for monoterpene and OVOC, due to its stronger dependency on light and temperature and more sensitivity to climatological conditions.

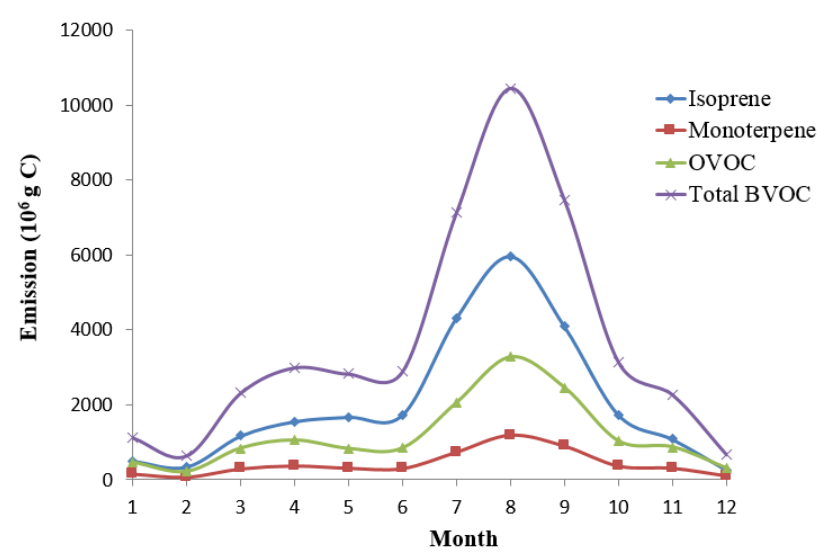

Figure 2. The monthly variations of BVOC emissions in Guangzhou, 2012 


\subsection{Factors affecting BVOC emission estimation}

To analyse the uncertainty from different emission factors of vegetation types, local emission factors and default values provided by the model were inputted into GloBEIS, respectively. The total BVOC emission calculated by model default emission rates in Guangzhou was $10.6 \mathrm{kt}$ in 2012, and the area-averaged emission was $14.35 \mathrm{t} /\left(\mathrm{km}^{2} \cdot \mathrm{a}\right)$, of which isoprene contributed about $60.3 \%\left(6.4 \mathrm{kt}, 8.65 \mathrm{t} /\left(\mathrm{km}^{2} \cdot \mathrm{a}\right)\right)$, monoterpenes about $10.7 \%$ $\left(1.14 \mathrm{kt}, 1.54 \mathrm{t} /\left(\mathrm{km}^{2} \cdot \mathrm{a}\right)\right)$ and OVOC about $29 \%$ (3.07 kt, 4.16 $\left.\mathrm{t} /\left(\mathrm{km}^{2} \cdot \mathrm{a}\right)\right)$. Compared to results in Section 3.1, estimation from model default emission factors show similar monthly variations but great difference in total emissions $(41.8 \%$ higher), indicating the importance of emission factors for BVOC emission estimation.

GloBEIS assumes that BVOC emissions are related to the variations of leaf area index, for the percentage of new and old leaves would affect the estimation of isoprene emission, meanwhile, relative humidity and wind speed would affect the vegetation metabolism and BVOC diffusion. Therefore, LAI, wind speed and relative humidity were inputted into GloBEIS to correct the estimation. The total BVOC emission after correction was $4.39 \mathrm{kt}$ and the area-averaged emission was 5.93 $\mathrm{t} /\left(\mathrm{km}^{2} \cdot \mathrm{a}\right)$, of which isoprene contributed about $55.7 \%(2.44 \mathrm{kt}$, $\left.3.38 \mathrm{t} /\left(\mathrm{km}^{2} \cdot \mathrm{a}\right)\right)$, monoterpenes about $11.9 \%(0.52 \mathrm{kt}, 0.72$ $\left.\mathrm{t} /\left(\mathrm{km}^{2} \cdot \mathrm{a}\right)\right)$ and OVOC about $32.4 \%\left(1.42 \mathrm{kt}, 1.97 \mathrm{t} /\left(\mathrm{km}^{2} \cdot \mathrm{a}\right)\right)$. Compared to results in Section 3.1, the total BVOC emission is a little lower, but the percentage of isoprene is higher, inferring that correction factors have greater effects on isoprene than other BVOCs. Monthly variations are similar to Figure 2, but the peak value appeared in August and emissions in summer were much higher than those in other seasons. It is due to the significant temporal variations of correction factors, which enlarge the difference of BVOC emissions in different periods. To validate the estimation in our study, comparisons of the total BVOC emissions and percentage of the chemical species were made with other studies. Table 2 and 3 lists the results and associated information from relevant studies. The area-averaged BVOC emission from local and default emission factors are much higher than other studies, but results after correction are very close to that reported by Zheng et al. (2010) for PRD and $\mathrm{Hu}$ et al. (2001) for South China, and higher than that reported for all the China (Klinger et al., 2002) and the PRD region (Yang et al., 2001). Yang et al. (2001) only estimated natural hydrocarbon emissions from major dominant tree species in PRD, thus, the results is lower. As Guangzhou has a higher vegetation coverage rate (about 25\%) and higher temperature than other regions, it is reasonable that this region has a higher area-averaged BVOC emission than the nation as a whole. The difference of BVOC percentage are related to the difference of land cover and vegetation coverage.

\begin{tabular}{|l|l|l|l|}
\hline Study Area & Area(km $\left.{ }^{2}\right)$ & $\begin{array}{l}\text { Yearly BVOC } \\
\text { emission (t) }\end{array}$ & $\begin{array}{l}\text { BVOC } \\
\text { emission } \\
\text { per } \mathbf{~ k m}^{2} \\
\left(\mathbf{t} /\left(\mathbf{k m}^{2} \cdot \mathbf{a}\right) \mathbf{)}\right.\end{array}$ \\
\hline China & $0.96 \times 10^{7}$ & $2.1 \times 10^{13}$ & 2.2 \\
\hline PRD & $5.8 \times 10^{4}$ & $2.0 \times 10^{5}$ & 3.4 \\
\hline South China & $5.3 \times 10^{5}$ & $2.5 \times 10^{6} \sim 3 \times 10^{6}$ & $4.71-4.66$ \\
\hline PRD & $4.7 \times 10^{4}$ & $3.0 \times 10^{5}$ & 6.28 \\
\hline HongKong & $1.1 \times 10^{3}$ & $9.76 \times 10^{3}$ & 7.8 \\
\hline Guangzhou $^{(1)}$ & $0.74 \times 10^{4}$ & $6.17 \times 10^{4}$ & 8.34 \\
\hline Guangzhou $^{(2)}$ & $0.74 \times 10^{4}$ & $10.6 \times 10^{4}$ & 14.35 \\
\hline Guangzhou $^{(3)}$ & $0.74 \times 10^{4}$ & $4.39 \times 10^{4}$ & 5.93 \\
\hline
\end{tabular}

Table 2. Comparison with BVOC emissions other studies

\begin{tabular}{|l|l|l|l|}
\hline Study area & $\begin{array}{l}\text { Isoprene } \\
(\mathbf{\%})\end{array}$ & $\begin{array}{l}\text { Monoterpenes } \\
(\%)\end{array}$ & $\begin{array}{l}\text { OVOCs } \\
(\%)\end{array}$ \\
\hline China & 28 & 19 & 52 \\
\hline PRD & 25 & 34 & 41 \\
\hline Hong Kong & 30 & 40 & 30 \\
\hline Guangzhou $^{(1)}$ & 46 & 16 & 38 \\
\hline Guangzhou $^{(2)}$ & 60 & 11 & 29 \\
\hline Guangzhou $^{(3)}$ & 56 & 12 & 32 \\
\hline
\end{tabular}

Table 3. Comparison with percentage of each chemical species in other studies

*(1) is the results from local emission factors; (2) is the results from default factors; and (3) is the results after corrections.

\subsection{Spatio-temperal characteristics of BVOC emissions in Guangzhou}

Figure 3 shows the spatial distribution of isoprene, monoterpenes, OVOC and total BVOC emissions estimated after correction. Overall, BVOC emissions are mainly distributed in the east-western of Conghua, the north of Zengcheng and the border of Huadu and Conghua, mostly covered by evergreen broadleaf forest with high emission factor. Areas of relatively high BVOC emission are located in the middle of Conghua, south of Panyu and Nansha district covered with cropland and shrubland, and areas of BVOC emission below $50 \mathrm{~kg} /\left(\mathrm{km}^{2} \cdot \mathrm{a}\right)$ are distributed in highly urbanized areas like Tianhe, Yuexiu, Liwan and Haizhu district, where lots of land has been developed into urban land due to the promotion of construction industry. Spatial characteristic of BVOC emission is caused by the forest distribution pattern in Guangzhou, where areas of forest in northern Conghua and Zengcheng make up two-thirds of that in Guangzhou, and forests in the East and South only account for $2.4 \%$ of that in the north, while green space in the districts such as Haizhu, Liwan, Yuexiu decreased quickly due to the urban expansion.

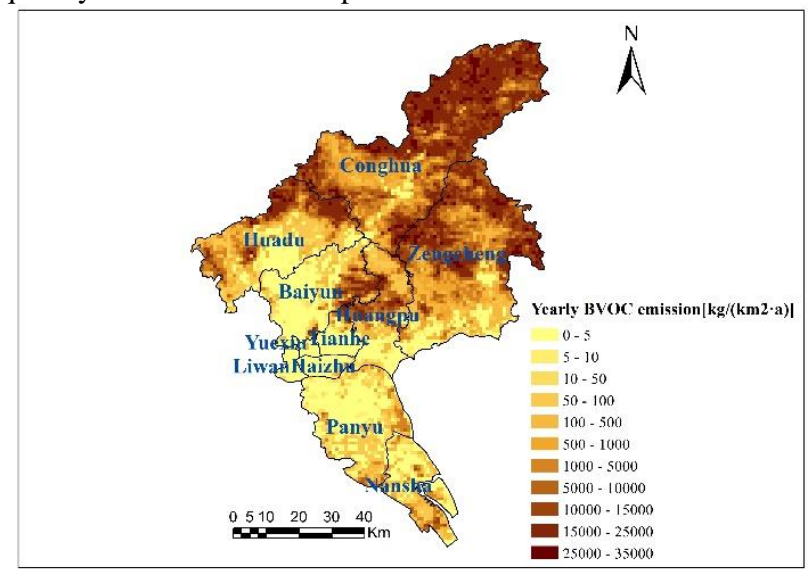

Figure 3. Spatial distribution of the total biogenic VOC emissions in Guangzhou, 2012

Spatial distribution of isoprene, monoterpene and other VOCs in Figure 4 are basically similar to that of total BVOCs, but slightly different. As isoprene is mainly emitted by broadleaf forest, their spatial distributions are very similar. Conghua and Zengcheng mainly covered by broadleaf forest are also the high emission areas of isoprene. Monoterpenes mainly come from coniferous and mixed forest, which are scattered in Huadu, Baiyun and Zengcheng. However, the spatial difference of isoprene was more significant, and the maximum emission was 
four orders of magnitude different from the minimum emission, as in shown in Table 4. Conghua contributed more than half of the BVOC emissions to the city, while Haizhu, Liwan and Yuexiu play negligible roles in the emissions.

Seasonal variations of BVOC emissions are displayed in Figure 5. Highest emission of BVOC, isoprene, monoterpene and other VOC occurred in summer, with value of $2.71 \mathrm{kt}, 1.38 \mathrm{kt}, 0.39 \mathrm{kt}$ and $0.94 \mathrm{kt}$ and contribution of $43.9 \%, 49 \%, 39.5 \%$ and $39.6 \%$ to the whole year, respectively. It is caused by high temperature and strong sunlight in summer. Lowest emission appeared in winter under the condition of low temperature and weak sunshine. Seasonal difference of isoprene is especially obvious, for emission in summer is seven times as much as that in winter.
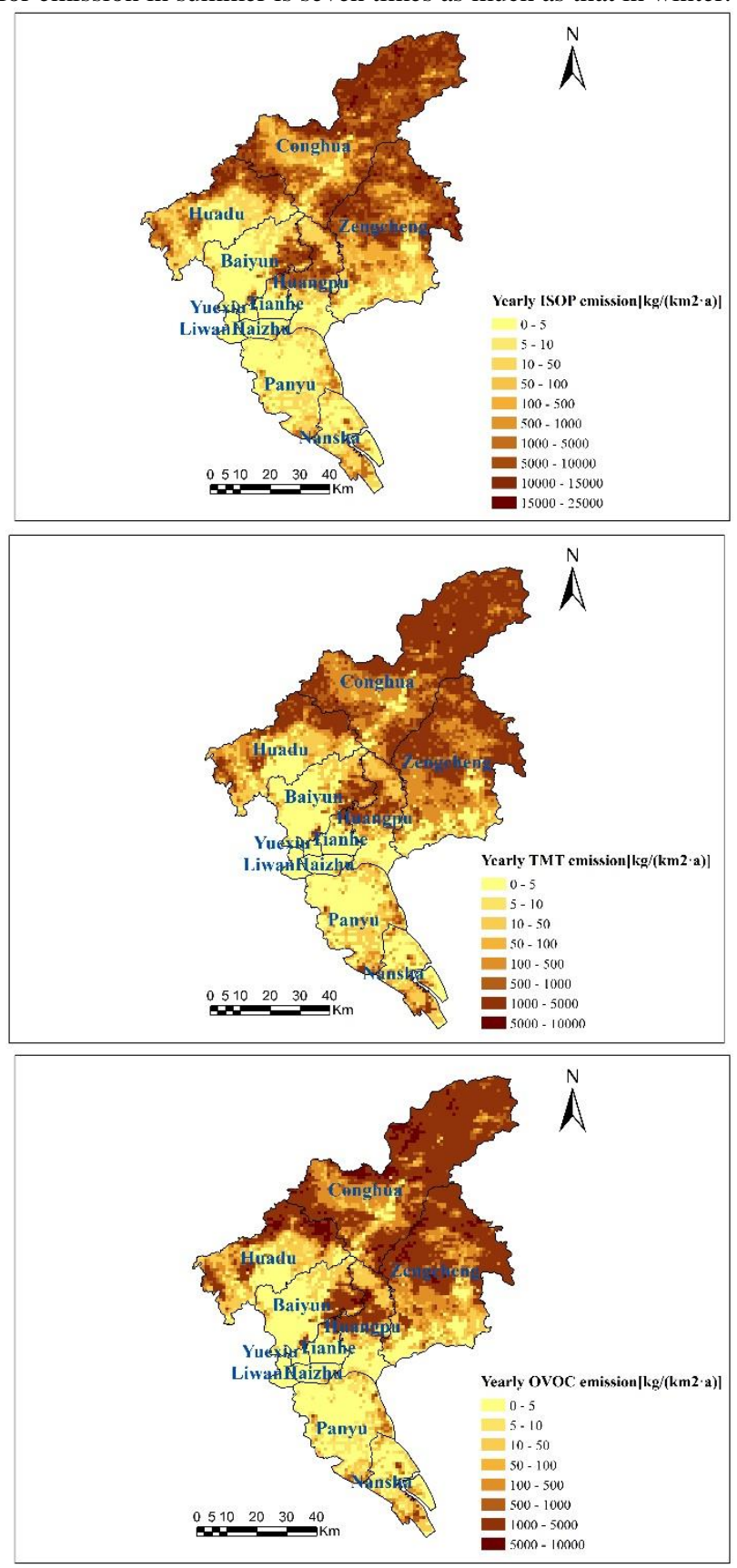

Figure 4. Spatial distribution of ISOP, TMT and OVOC in Guangzhou, 2012

\begin{tabular}{|l|l|l|l|l|}
\hline District & $\begin{array}{l}\text { BVOC } \\
(\text { Ton, \%) }\end{array}$ & $\begin{array}{l}\text { ISOP } \\
(\text { Ton, \%) }\end{array}$ & $\begin{array}{l}\text { TMT } \\
(\text { Ton, \%) }\end{array}$ & $\begin{array}{l}\text { OVOC } \\
(\text { Ton, \%) }\end{array}$ \\
\hline Nansha & 324.1 & 128.5 & 73.7 & 121.9 \\
& $(0.74)$ & $(0.53)$ & $(1.41)$ & $(0.86)$ \\
\hline Panyu & 235.4 & 81.9 & 61 & 92.5 \\
& $(0.54)$ & $(0.34)$ & $(1.17)$ & $(0.65)$ \\
\hline Haizhu & 4.2 & 1.4 & 1.2 & 1.6 \\
& $(0.01)$ & $(0.01)$ & $(0.02)$ & $(0.01)$ \\
\hline Liwan & $0.14(0)$ & $0.03(0)$ & $0.06(0)$ & $0.05(0)$ \\
\hline Huangpu & 1742.1 & 993.9 & 207.4 & 540.8 \\
& $(3.97)$ & $(4.07)$ & $(3.97)$ & $(3.81)$ \\
\hline Yuexiu & 3.7 & 1.5 & 0.8 & 1.4 \\
& $(0.01)$ & $(0.01)$ & $(0.02)$ & $(0.01)$ \\
\hline Tianhe & 176.9 & 89 & 25.6 & 62.3 \\
& $(0.4)$ & $(0.36)$ & $(0.49)$ & $(0.44)$ \\
\hline Baiyun & 1354.3 & 773 & 155.4 & 425.9 \\
& $(3.09)$ & $(3.16)$ & $(2.98)$ & $(3)$ \\
\hline Huadu & 4330.8 & 2342.6 & 575.2 & 1413 \\
& $(9.87)$ & $(9.58)$ & $(11.02)$ & $(9.94)$ \\
\hline Zengcheng & 12000.2 & 6805.1 & 1379.8 & 3815.3 \\
& $(27.35)$ & $(27.84)$ & $(26.44)$ & $(26.84)$ \\
\hline Conghua & 23706.3 & 13229.6 & 2738.6 & 7738.1 \\
& $(54.02)$ & $(54.1)$ & $(52.48)$ & $(54.44)$ \\
\hline
\end{tabular}

Table 4. Percentage of BVOC emission in each district, Guangzhou

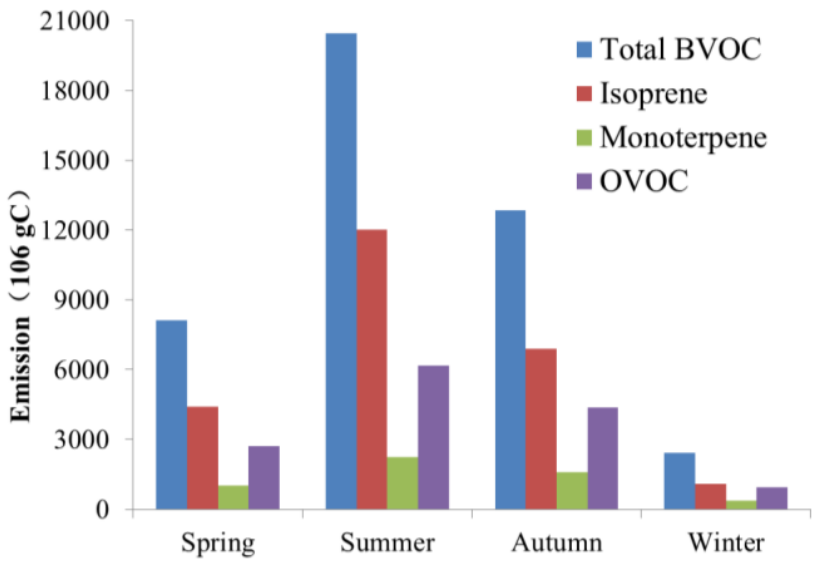

Figure 5. Seasonal variations of BVOC emissions in Guangzhou, 2012

\section{CONCLUSION}

This study utilized the GloBEIS model to develop a highly resolved BVOC emission inventory for Guangzhou, using satellite-retrieved land cover data, cloud product and leaf area index (LAI), observed meteorological data and local emission rates for land cover types. The total BVOC emission in Guangzhou for the year of 2012 was $4.39 \mathrm{kt}$, of which isoprene contributed about $55.7 \%$ (2.44 kt)), monoterpenes about $11.9 \%$ $(0.52 \mathrm{kt})$ and OVOC about $32.4 \%(1.42 \mathrm{kt})$. Comparison with other studies indicate that estimation of BVOC using local emission rates and correction factors in this study is reasonable. BVOC emissions in Guangzhou exhibit an obvious monthly and seasonal variation, with the maximum in July and summer and the minimum in January and winter. These emissions mainly come from east-western of Conghua, the north of Zengcheng 
and the border of Huadu and Conghua, with high coverage of evergreen broadleaf forest.

\section{REFERENCES}

Adams, J. M., Constable, J.V., Guenther, A.B., Zimmerman, P., 2001. An estimate of natural volatile organic compound emissions from vegetation since the last glacial maximum. Chemosphere-Global Change Science, Vol. 3, pp. 73-91, doi: https://doi.org/10.1016/S1465-9972(00)00023-4 .

Arneth, A., Schurgers, G., Hickler, T., Miller, P.A., 2008. Effects of species composition, land surface cover, $\mathrm{CO} 2$ concentration and climate on isoprene emissions from European forests. Plant Biology, Vol. 10, pp. 150-162, doi: https://doi.org/10.1055/s-2007-965247 .

Carslaw, K.S., Boucher, O., Spracklen, D.V., Mann, G.W., Rae, J.G.L., Woodward, S., Kulmala, M., 2010. A review of natural aerosol interactions and feedbacks within the Earth system. Atmospheric Chemistry And Physics, Vol. 10, pp. 1701-1737, doi: https://doi.org/10.5194/acp-10-1701-2010 .

Chi, Y.Q., Xie, S.D., 2011. Spatiotemporal inventory of biogenic volatile organic compound emissions in China based on vegetation volume and production. Advanced Materials Research, Vol. 356, pp. 2579-2582, doi: https://doi.org/10.4028/www.scientific.net/AMR.356-360.2579

Fu, Y., Liao, H., 2012. Simulation of the interannual variations of biogenic emissions of volatile organic compounds in China: impacts on tropospheric ozone and secondary organic aerosol. Atmospheric Environment, Vol. 59, pp. 170-185, doi: https://doi.org/10.1016/j.atmosenv.2012.05.053 .

Goldstein, A.H., Galbally, I.E., 2007. Known and unexplored organic constituents in the Earth's atmosphere. Environmental Science \& Technology, Vol. 41, pp. 1514-1521, doi: https://doi.org/10.1021/es072476p .

Guenther, A., Hewitt, C.N., Erickson, D., Fall, R., Geron, C., Graedel, T., Harley, P., Klinger, L., Lerdau, M., Mckay, W.A., Pierce, T., Scholes, B., Steinbrecher, R., Tallamraju, R., Taylor, J., Zimmerman, P., 1995. A global model of natural volatile organic compound emissions. Journal of Geophysical ResearchAtmospheres, Vol. 100, pp. 8873-8892, doi: http://dx.doi.org/10.1029/94JD02950 .

Guenther, A., Karl, T., Harley, P., Wiedinmyer, C., Palmer, P.I., Geron, C., 2006. Estimates of global terrestrial isoprene emissions using MEGAN (Model of Emissions of Gases and Aerosols from Nature). Atmospheric Chemistry Physics, Vol. 6, pp. 3181-3210, doi: https://doi.org/10.5194/acp-6-3181-2006 .

Hu, Y.T., Zhang, Y.H., Xie, S.D., Zeng, L.M., 2001 Development of Biogenic VOC emissions Inventory with High temporal and spatial resolution, Environmental Science, Vol. 22 pp. 1-6.

Karl, M., Guenther, A., Koble, R., Leip, A., Seufert, G., 2009. A new European plant-specific emission inventory of biogenic volatile organic compounds for use in atmospheric transport models. Biogeosciences, Vol. 6, pp. 1059-1087, doi: https://doi.org/10.5194/bg-6-1059-2009 .
Klinger, L.F., Li, Q.J., Guenther, A.B., Greenberg, J.P., Baker, B., Bai, J.H., 2002. Assessment of volatile organic compound emissions from ecosystems of China. Journal of Geophysical Research-Atmospheres, Vol. 107, D21，4603， doi: https://doi.org/10.1029/2001JD001076 .

Li, L.Y., Chen, Y., Xie, S.D., 2013. Spatial-temporal variation of biogenic volatile organic compounds emissions in China. Environmental Pollution, Vol. 182, pp. 157-168, doi: https://doi.org/10.1016/j.envpol.2013.06.042 .

Li, M., Huang, X., Li, J., Song, Y., 2012. Estimation of biogenic volatile organic compound (BVOC) emissions from the terrestrial ecosystem in China using real-time remote sensing data. Atmospheric Chemistry and Physics Discussions, Vol. 12, pp. 6551-6592, doi: https://doi.org/10.5194/acpd-126551-2012

Nozière, B., González, N.J.D., Borg-Karlson, A.-K., Pei, Y., Redeby, J.P., Krejci, R., Dommen, J., Prevot, A.S.H., Anthonsen, T., 2011. Atmospheric chemistry in stereo: a new look at secondary organic aerosols from isoprene. Geophysical Research Letters, Vol. 38, L11807, doi: http://dx.doi.org/10.1029/2011GL047323 .

Schurgers, G., Arneth, A., Holzinger, R., Goldstein, A.H., 2009. Process-based modelling of biogenic monoterpene emissions combining production and release from storage. Atmospheric Chemistry Physics, Vol. 9, pp. 3409-3423, doi: https://doi.org/10.5194/acp-9-3409-2009 .

Sindelarova, K., Granier, C., Bouarar, I., Guenther, A., Tilmes, S., Stavrakou, T., Müller, J.-F., Kuhn, U., Stefani, P., Knorr, W., 2014. Global data set of biogenic VOC emissions calculated by the MEGAN model over the last 30 years. Atmospheric Chemistry Physics, Vol. 14, pp. 9317-9341, doi: https://doi.org/10.5194/acp-14-9317-2014 .

Steinbrecher, R., Smiatek, G., Köble, R., Seufert, G., Theloke, J., Hauff, K., Ciccioli, P., Vautard, R., Curci, G., 2009. Intraand inter-annual variability of VOC emissions from natural and semi-natural vegetation in Europe and neighbouring countries. Atmospheric Environment, Vol. 43, pp. 1380-1391, doi: https://doi.org/10.1016/j.atmosenv.2008.09.072 .

Tao Z., Jain, A.K., 2005. Modeling of global biogenic emissions for key indirect greenhouse gases and their response to atmospheric $\mathrm{CO} 2$ increases and changes in land cover and climate. Journal of Geophysical Research-Atmospheres, Vol. 110, D21309, doi: https://doi.org/10.1029/2005JD005874 .

Tie, X.X., Li, G.H., Ying, Z.M., Guenther, A., Madronich, S., 2006. Biogenic emissions of isoprenoids and NO in China and comparison to anthropogenic emissions. Science of the Total Environment, Vol. 371, pp. 238-251, doi: https://doi.org/10.1016/j.scitotenv.2006.06.025 .

Yarwood G., Wilson G., Shepard S. Guenther A., 2007. User's guide to the global biosphere emissions and interactions system (GloBEIS) version 3. ENVIRON International Corporation, California,

Yang, D.J., Bai, Y.H., Li, J.L., et al., 2001. Study on hydrocarbon compounds from natural source in the Pearl River Delta area. China Environmental Science, Vol. 21 , pp. 422-426. 
Wang, X.M., Situ, S.P., Guenther, A., Chen, F., Wu, Z.Y., Xia, B.C., Wang, T.J., 2011. Spatiotemporal variability of biogenic terpenoid emissions in Pearl River Delta, China, with highresolution land-cover and meteorological data. Tellus B: Chemical and Physical Meteorology, Vol. 63, pp. 241-254, doi: https://doi.org/10.1111/j.1600-0889.2010.00523.x .

Zheng, J.Y., Zheng, Z.Y., Yu, Y.F., Zhong, L.J., 2010. Temporal, spatial characteristics and uncertainty of biogenic VOC emissions in the Pearl River Delta region, China. Atmospheric Environment, Vol. 44, pp. 1960-1969, doi: https://doi.org/10.1016/j.atmosenv.2010.03.001 . 